\title{
Microbial Profile of a Calcareous Soil of South Tamil Nadu, India
}

\author{
P. Maheshwari ${ }^{*}$ and S. Anthoni Raj ${ }^{2}$ \\ ${ }^{1}$ SRSIAT, Department of Agricultural Microbiology, Dindigul, Tamil Nadu, India \\ ${ }^{2}$ Department of Agriculture Microbiology, Trichy, Tamil Nadu, India
}

*Corresponding author

\section{A B S T R A C T}

\begin{tabular}{|l|}
\hline Ke y w or d s \\
$\begin{array}{l}\text { Bacteria, Fungi, } \\
\text { Actinomycetes, } \\
\text { Azotobacter, } \\
\text { Diazotrophs and } \\
\text { Phosphobacteria }\end{array}$ \\
\hline Article Info \\
\hline $\begin{array}{l}\text { Accepted: } \\
\text { 25 September } 2020 \\
\text { Available Online: } \\
\text { 10 October } 2020\end{array}$ \\
\hline \hline
\end{tabular}

\section{Introduction}

Calcareous soils are commonly observed in the central, western and southern states of India, including Maharashtra, western parts of Madhya Pradesh, Gujarat and some parts of Andhra Pradesh, Karnataka and Tamil Nadu. Black soils are found scattered in Tirunelveli, Virudhunagar, Tuticorin, parts of Madurai, Coimbatore, Dharmapuri, Vellore, Trichirapalli, Salem, Cuddalore and Villupuram districts of Tamil Nadu. Agriculture is mainly depends upon the North East Rainfall in southern Tamil Nadu. The farmers were mainly cultivated Sorghum, maize, cotton, ragi and rice in Tamil Nadu. So the microbial community study is important for knowing the soil aggregation and fertility soil in this location. In general, the carbonate content is more in calcareous soil, which is not suitable for uptake of major and minor nutrients in the soil.

Soil and microflora are inseparable, interrelated and interdependent as the soil is the abode for the microbes which are responsible for the productivity and fertility. Black cotton soil is subjected to dry and hot weather during summer, leading to decline in moisture and desiccation. The mean annual rainfall at Aruppukottai where the study was conducted is about $700-1000 \mathrm{~mm}$ out of 
which about $300-350 \mathrm{~mm}$ is recorded in a period of about three months in Oct-Dec when rainfed sorghum is raised. During the other months the soil therefore appears dry and friable after the cropping season with very low moisture in summer. The soil show very scanty weed population.

Indian farmers are highly dependent on rainfall and all activities of agriculture starting from sowing to post harvest are affected either directly or indirectly by weather especially by rainfall. In the vagaries of weather condition and make it us suitable condition for cultivation to utilize such type of soil for improving the agricultural activity without any yield reduction. Soil microbial profile is affected by biotic and abiotic factors such as soil texture affected by biotic and abiotic factors such as soil texture (de Vries $e t$ al., 2012), pH (Lange et al., 2014), temperature (Medeiros et al., 2006), seasonality (Cao et al., 2011) and vegetation (Epron et al., 2011).

\section{Materials and Methods}

The microbial profile of the soil was monitored at monthly intervals in the Aruppukottai soil. The soil samples were collected from the field no $\mathrm{A}_{2}$ of Regional Research Station, Aruppukottai at monthly intervals up to one year. In this soil sample, the total bacteria, fungi, actinomycetes, diazotroph, Azotobacter and phosphobacteria were enumerated as per the standard plate count (Allen, 1953). Using nutrient agar for bacteria, Martin's Rose Bengal agar and Kenknight's agar for fungi and actinomycetes respectively. The diazotrophs, Azotobacter and phosphobacteria were enumerated in diazotroph medium, Medium No. 77 and Sperber's hydroxy apatite agar.

The sorghum roots and the rhizosphere soil samples were collected from the major sorghum growing area of South Tamil Nadu viz., Aruppukottai, Kamuthi, Pudhur, Kovilpatti and Madurai. Sorghum crop rhizosphere soil was examined for the presence of Azospirillum, VA mycorrhizal spores and the roots of sorghum plants were analyzed for VAM - mycorrhizal infection. Sorghum crop root samples were examined for the presence of Azospirillum and the VAM - mycorrhizal infection. The presence of Azospirillum in the subterranean roots of sorghum root sample was tested following the method of Dobereiner and Day (1976). The Azospirillum isolates were characterized by gram staining, utilization of carbon sources and biotin requirements.

The sorghum crop rhizosphere soil was examined for the presence of VA mycorrhizal spores by wet sieving and decanting method of Gerdemann and Nicolson (1963). The roots of sorghum plants were analysed for VAM mycorrhizal infection by clearing and staining method of Phillips and Hayman (1970). The mycorrhizal infection was calculated using the following formula expressed in percentage.

Root infection $(\%)=\frac{\text { Number of root segments infected }}{\text { Number of root segment examined }} \times 100$

\section{Results and Discussion}

The microbial profile of the calcareous soil of Aruppukottai over a period of a year was assessed and presented in Table 1 and illustrated in Fig.1. In the present study the total bacteria, fungi, actinomycetes, diazotrophs, Azotobacter and phosphobacteria were present in large numbers in the calcareous black cotton soil even during summer when the soil was dry and the moisture was low i.e., $6 . .3$ per cent. The soil moisture ranged from 5.4 to 24.2 per cent. A maximum of $79 \times 10^{6} \mathrm{cfu} \mathrm{g}^{-1}$ bacterial population was observed in July with the lowest of $4 \times 10^{6} \mathrm{cfu} \mathrm{g}^{-1}$ in March. The population increased during the cropping 
period and declined after harvest. The soil microbial profile is altered by season, soil organic matter (Mellado-Va'zquez et al., 2016), plant root exudates, soil carbon dynamics (Chen et al., 2016), soil type, soil fertility, soil $\mathrm{pH}$, soil moisture and soil temperature (Voroney and Heck 2015). Plant root exudates are attract some microorganism mainly gram negative bacteria because which is one of the important carbon source for bacteria (Mellado-Va'zquez et al., 2019).

The microbial profile is also affected by ecological functions like decomposition, accumulation of soil organic matter and nutrient cycling (Liang et al., 2017). Hence, it is essential to study about the relationship between dynamics of microbial profile and environmental functions.

The soil exhibited a lesser population of fungi when compared to other organisms. During the cropping period actinomycetes and fungal population increased. The fungi were relatively higher during the cropping period Sep-Dec but declined afterwards. The lowest fungal population of $2 \times 10^{4} \mathrm{cfu}^{-1}$ was observed in March month and the highest population of $22 \times 10^{4} \mathrm{cfu} \mathrm{g}^{-1}$ in November i.e., during the cropping period. The rhizosphere soil fungal population contribute to the soil aggregation through fungal hyphae and promotes the soil fertility status (Duchicela et al., 2013). The fungal population is always inversely proportional to the bacteria population (Siciliano et al., 2014)

In the present study the actinomycetes population was higher after the receipt of the rainfall. A similar finding was also reported by Tsao et al., (1960). The type of microflora varies with the soil and season. The microflora of soils of Tamil Nadu has been studied in the past by Ramasami (1966) who reported the bacterial population in the surface soil varied from as low as 20,000 to as high as 16 lakh cfu per gram of dry soil. Fungi and actinomycetes population recorded 15935 and 57780 cfu per gram of soil. Indira Raja and Raj (1979) observed bacteria, fungi and actinomycetes populations in black wet land soil and black garden land soil. The bacteria, fungi and actinomycetes population were higher in the black garden land soil than in wet land soil.

The diazotrophs recorded a higher population in February with $254 \times 10^{4} \mathrm{cfu} \mathrm{g}^{-1}$ but declined until October with a subsequent increase when the cropping period commenced. Diazotroph bacteria can fix the atmospheric nitrogen and provides the plant. But the diazotrophic bacterial population might be suppressed by the application of high dose of nitrogenous fertilizers (Yeoh et al., 2016).

The result on the enumeration of Azotobacter showed that they were generally higher in April - June during the summer period. Subsequently there was a decline followed by an increase in September, October during the cropping period. There was a marked increase in the population of these organisms after December when the harvest was over. The higher number of Azotobacter and phosphobacteria observed in the black cotton soil might be due to their capability to form cyst and spores. For the cyst formation in Azotobacter the calcium requirement is there which is readily available in black soil.

The cyst coat components are synthesized when sufficient quantities of $\mathrm{Ca}$ ions are present in soil (Neeru Narula et al., 1998). Such cyst formation and polysaccharide production might have aided the bacterium to survive in the soil at moisture stress besides favouring soil aggregate formation which improves infiltration rate and fertility of soil (Sivapriya and Pasupuleti Reddy Priya 2017). 
The result on the enumeration of phosphobacteria showed that they were generally higher in April - June during the summer period. Subsequently there was a decline followed by an increase in September, October during the cropping period. There was a marked increase in the population of these organisms after December when the harvest was over. Phosphobacterial colony character of the presumption test is the presence of halo zone around the colony.

The phosphobacteria comprises of a variety of organisms primarily Bacillus spp. besides Pseudomonas and others. Bacillus spp. forms endospores readily and survive the hot condition. For the formation of endospores, Ca-dipicolinic acid complex is to be formed for which also soil $\mathrm{Ca}$ can help. Hence Bacillus can survive well in this type of soil (Setlow, 2013; Shiwei Wang et al., 2015).

Phosphorus, a key element in crop production is very low in calcareous (black cotton) soil and its availability is still low due to fixation. Application of phosphatic fertilizers to the soils also faces the same fate of fixation owing to fixation by calcium in soils above neutrality and due to iron and aluminum in acid soils. These fixed phosphorus is render solublize only by the action of phosphobacteria through the production of organic acids (lactic, gluuconic, isobutric, propionic, fumaric and isovaleric), vitamins, growth hormones (Indole acetic acid - IAA and Gibberllic acid - GA3). These substances are secreted by the Pseudomonas and Bacillus (Ponmurugan and Gopi 2006).

Phosphorus solubilizing microbes includes bacteria (Azotobacter, Bacillus, Burkholderia, Enterobacter, Erwinia, Kushneria, Paenibacillus) Ralstonia, Rhizobium, Rhodococcus, Serratia, Bradyrhizobium, Salmonella, Sinomonas, and Thiobacillus fungi (Achrothcium, Alternaria, Arthrobotrys,
Aspergillus, Cephalosporium, Cladosporium, Curvularia, Cunninghamella, Chaetomium, Fusarium, Glomus, Helminthosporium, Micromonospora, Mortierella, Myrothecium, Oidiodendron, Paecilomyces, Penicillium, Phoma, Pichia fermentans, Mucor, Candida, Populospora, Pythium, Rhizoctonia, Rhizopus, Saccharomyces, Schizosaccharomyces, Schwanniomyces, Sclerotium, Torula, Trichoderma, and Yarrowia and actinomycetes (Streptomyces) (Kalayu, 2019).

Phosphobacteria produces organic acids and these acids decreasing the soil $\mathrm{pH}$ that can favor the dissolution of calcium bound phosphorous. These organic acids proliferate the plant root system ultimately improves the uptake of nutrients and water (Marasco et al., 2013). The mode of action of phosphobacteria is in the soil from insoluble form of phosphate into soluble form through production of organic acids and thereby lowering the soil $\mathrm{pH}$. This $\mathrm{pH}$ could be able to mineralize the organic form of phosphates into acid phosphates (Behera et al., 2017).

The results on the survey of VAM spores in soil and colonization of VAM and Azospirillum in sorghum plants are presented in Table 2 and 3. The soil and sorghum roots were collected from the major sorghum growing area of South Tamil Nadu viz., Aruppukottai, Kamuthi, Pudhur, Kovilpatti and Madurai and the VAM spores in soil and Azospirillum and VAM root infection were assessed. All these soils exhibited VAM spores ranging from 2 to $9 / 100 \mathrm{~g}$ of soil.

The soil fertility index is mainly depends upon the presence of VAM spores and the VAM spore distribution is vary in different soil profile (Sanjoy Kumar et al., 2011). Hence, the VAM spore count is essential to know about the fertility status of the soil. 
Table.1 Microbial profile* of a calcareous soil of Aruppukottai

\begin{tabular}{|c|c|c|c|c|c|c|c|c|}
\hline \multirow{2}{*}{$\begin{array}{l}\text { Sl. } \\
\text { No. }\end{array}$} & \multirow[t]{2}{*}{ Month* } & \multirow{2}{*}{$\begin{array}{c}\text { Moisture } \\
\%\end{array}$} & \multicolumn{6}{|c|}{ Microbial population** } \\
\hline & & & $\begin{array}{l}\text { Total bacteria } \\
\qquad \times 1^{6}\end{array}$ & $\begin{array}{l}\text { Fungi } \\
\times 10^{4}\end{array}$ & $\begin{array}{l}\text { Actinomycetes } x \\
\qquad 10^{4}\end{array}$ & $\begin{array}{l}\text { Diazotrophs } \\
\qquad \times 10^{4}\end{array}$ & $\begin{array}{c}\text { Phosphobacteria } x \\
1^{3}\end{array}$ & $\begin{array}{c}\text { Azotobacter } \\
\times \mathbf{1 0}^{3}\end{array}$ \\
\hline 1. & April & 11.8 & $60(1.78)$ & $17(1.23)$ & $<1(0.00)$ & $180(2.26)$ & $181(2.26)$ & $103(2.01)$ \\
\hline 2. & May & 11.6 & $16(1.20)$ & $5(0.69)$ & $37(1.56)$ & $20(1.30)$ & $37(1.57)$ & $32(1.50)$ \\
\hline 3. & June & 6.3 & $<1(0.00)$ & $16(1.20)$ & $<1(0.00)$ & $<1(0.00)$ & $88(1.94)$ & $60(1.78)$ \\
\hline 4. & July & 22.0 & $79(1.89)$ & $11(1.04)$ & $36(1.55)$ & $9(0.95)$ & $9(0.95)$ & $15(1.18)$ \\
\hline 5. & Aug & 5.4 & $8(0.90)$ & $9(0.95)$ & $33(1.52)$ & $<1(0.00)$ & $<1(0.00)$ & $6(0.78)$ \\
\hline 6. & Sep & 22.0 & $24(1.40)$ & $10(1.00)$ & $24(1.38)$ & $12(1.08)$ & $51(1.71)$ & $13(1.11)$ \\
\hline 7. & Oct & 22.5 & $12(1.08)$ & $10(1.00)$ & $25(1.40)$ & $5(0.70)$ & $18(1.26)$ & $39(1.59)$ \\
\hline 8. & Nov & 24.2 & $10(1.00)$ & $22(1.34)$ & $30(1.47)$ & $42(1.62)$ & $11(1.04)$ & $36(1.55)$ \\
\hline 9. & Dec & 13.8 & $24(1.36)$ & $13(1.09)$ & $53(1.72)$ & $21(1.32)$ & $4(0.60)$ & $10(1.00)$ \\
\hline 10. & Jan & 12.1 & $32(1.5)$ & $5(0.69)$ & $27(1.43)$ & $105(2.02)$ & $64(1.81)$ & 43 (1.63) \\
\hline 11. & Feb & 12.4 & $6(0.78)$ & $11(1.04)$ & $32(1.51)$ & $254(2.41)$ & $46(1.66)$ & $49(1.69)$ \\
\hline 12. & Mar & 6.8 & $4(0.60)$ & $2(0.30)$ & $34(1.53)$ & $53(1.72)$ & $84(1.92)$ & $10(1.00)$ \\
\hline
\end{tabular}

** cfu g $^{-1}$ on oven dry basis; Figures in parentheses are log values

Table.2 Survey of VAM spores in soil, root colonization of VAM and Azospirillum in sorghum

\begin{tabular}{|c|l|l|c|c|c|}
\hline SI. No. & \multicolumn{1}{|c|}{ Location } & \multicolumn{1}{|c|}{ Soil type } & VAM spore (No/100 g of soil) & VAM root infection (\%) & Azospirillum \\
\hline 1. & Aruppukottai & Black cotton soil & 9 & 30 & 31 \\
\hline 2. & Pudhur & Black cotton soil & 5 & 71 \\
\hline 3. & Kamuthi & Black cotton soil & 9 & 42 & + \\
\hline 4. & Kovilpatti & Black cotton soil & 6 & 75 & + \\
\hline 5. & Madurai & Loamy soil & 2 & + \\
\hline
\end{tabular}

+ Present 
Table.3 Utilization of different carbon sources and biotin requirement of Azospirillum

\begin{tabular}{|c|l|c|c|c|c|c|c|c|}
\hline $\begin{array}{c}\text { Sl. } \\
\text { No. }\end{array}$ & $\begin{array}{c}\text { Azospirillum } \\
\text { isolate } \\
\text { location }\end{array}$ & Malate & Glucose & Fructose & Sucrose & Mannitol & $\begin{array}{c}\text { Carbon source } \\
\text { KGA }\end{array}$ & requirement \\
\hline 1. & Aruppukottai & + & - & - & - & - & - & No \\
\hline 2. & Kovilpatti & + & - & - & - & - & - & No \\
\hline 3. & Pudhur & + & + & + & - & + & + & Yes \\
\hline 4. & Kamuthi & + & + & + & - & + & + & Yes \\
\hline 5. & Madurai & + & + & + & - & + & + & Yes \\
\hline
\end{tabular}

+ Growth

- No growth

Table.4 Determination of carbonate content in soil

\begin{tabular}{|c|l|l|c|}
\hline Sl. No. & \multicolumn{1}{|c|}{ Location } & \multicolumn{1}{|c|}{ Soil type } & Carbonate content (\%) \\
\hline 1. & Aruppukottai & Black cotton soil & 2.5 \\
\hline 2. & Kovilpatti & Black cotton soil & 1.0 \\
\hline 3. & Madurai & Loamy soil & 0.7 \\
\hline
\end{tabular}

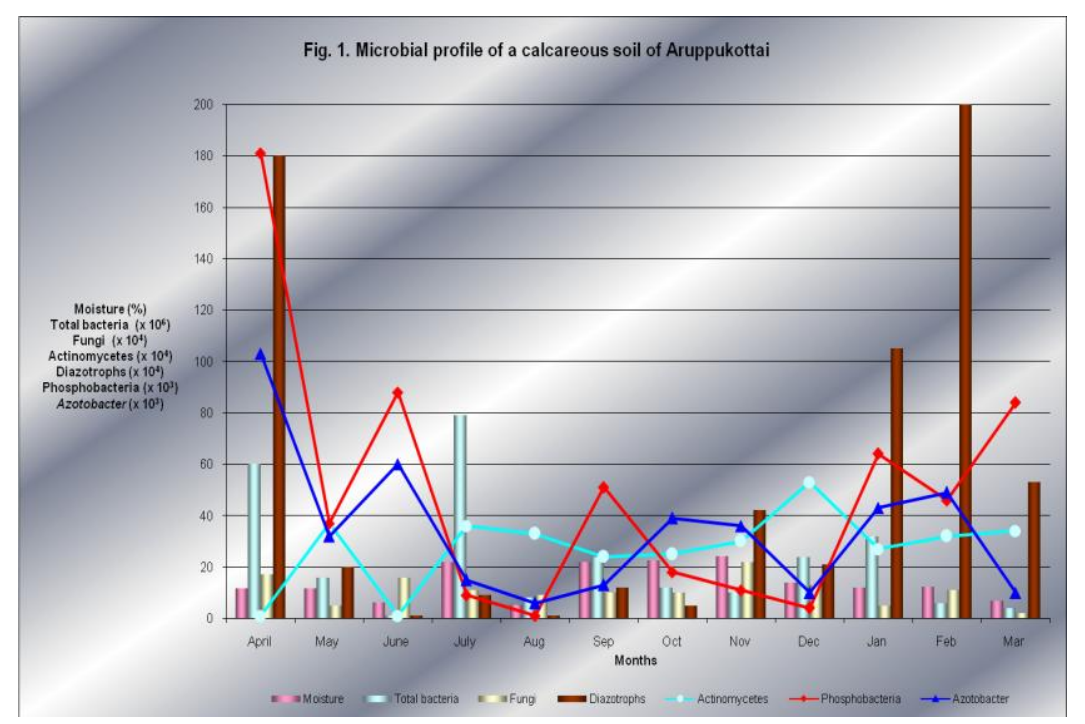

Aruppukottai soil and Kamudhi soil showed a higher number of VAM spores with 9 per 100g. The VAM root infection was higher with 71 percent in Kamudhi location but low with 30 percent in Aruppukottai sample. With a comparatively low VAM spore count with 2 numbers per $100 \mathrm{~g}$ in Madurai soil the root infection was higher with 75 percent indicating the potentiality of Madurai VAM. Based on the spore morphology the mycorrhiza was identified as Glomus sp. The VAM root infection is varying from plant to plant (Sanjoy Kumar et al., 2011). VAM fungi are ubiquitous in nature (Hayman, 1982). VAM fungi increases the nutrient availability, drought tolerance, controls soil borne pathogen, heavy metals tolerance and production growth hormones (Priyadarshini $e t$ al., 2017). VAM fungi can able to produce sugars and proteins (hydrophobins, glomalin, 
mucilages that can help to increase the soil aggregation (Owen et al., 2015).

Based on the growth in Nfb, 5 Azospirillum isolates were purified with repeated transfer on $\mathrm{N}$ free malate broth. They were characterized based on the morphology, Gram reaction, utilization of carbon sources and biotin requirements and the results are presented in Table 3.

Pudhur, Madurai and Kamudhi isolates utilized glucose, fructose, malate, and mannitol under nitrogen free condition. Sucrose was not utilized by any of these isolates. These isolates required biotin. Hence they are identified as A. lipoferum. Arppukottai and Kovilpatti isolates were able to grow in the absence of biotin. They were auxotrophic for biotin. Hence they are tentatively identified as $A$. brasilense.

Nitrogen is the major plant nutrient. The nitrogen content in Indian soil is very low. Application of chemical fertilizer is also lost by the rainfall or leaching. The nitrogen content in the soil is improved by application of Azospirillum or enrichment of the natural microflora. Application of Azospirillum could be able to produce phytohormones, defense against pathogens, tolerance to abiotic stress, increase the rate of mineral and water uptake (Josiane Fukami et al., 2018).

The results on the carbonate content of soils collected from different locations are presented in Table 4. Carbonate content was higher in Aruppukottai black cotton soil with 2.5 per cent followed by Kovilpatti black cotton soil with 1 per cent. The loamy soil of Madurai recorded 0.5 per cent of carbonate. High carbonate content with high $\mathrm{pH}$ affects the availability of macro and micro nutrients. In this condition, Phosphorus solubilizing microorganism play an vital role in phosphorus uptake from unavailable form of phosphorus to available form of phosphorus through organic acid and enzyme (phosphatases) (Awasthi et al., 2011).

In conclusion the lack of microbial proliferation in soil is often termed 'microbiotasis'. By contrast, this also supports a relatively constant biomass, which responds little to the input at fresh substrates. In the present study the soil was dry for most part of the year and there were higher number of microorganisms and there was not lack of organisms and no microbiotasis. The higher number of Azotobacter and phosphobacteria observed in the black cotton soil might be due to their capability to form cyst and spores. For the cyst formation in Azotobacter the calcium requirement is there which is readily available in black soil. The cyst coat components are synthesized when sufficient quantities of $\mathrm{Ca}$ ions are present in soil. Soil fertility defined as organic matter, chloride and nitrogen content was important that could be associated with richness of bacteria and fungi. The soil fertility status is depends upon the soil microflora and fauna. The natural soil microflora promotes the plant growth through the action of phytohormone, organic acid production, nutrient cycling, plant protection against pest and diseases, tolerance to biotic and abiotic stress, environmental friendly and cost saving technology.

The appearance of the soil and hotness prevailing in Southern Tamil Nadu during summer gives an impression that this soil might not have any microbiological activity particularly in summer. In the present study it was observed that in reality a lot of organisms survive in this soil particularly bacteria including Azotobacter, phosphobacteria, diazotrophs and actinomycetes and also fungi. The survival in higher numbers in black cotton soil might be due to the adaptability of the microbes to higher temperature and a low moisture status. Whereas the natural and 
applied microflora affected by the application of chemical fertilizers and pesticides.

\section{Acknowledgements}

I would like to thanks to Professor and Head (Dr. Siddeswaran), Farm Manager and all staff members of Regional Research Station (RRS), Aruppukottai for their timely help.

\section{References}

Allen, O.N. 1953. Experiments in soil bacteriology. Burges Publ. Co., Minneapolis, Minn. p. 156.

Awasthi, R., Tewari, R., and Nayyar H., 2011. Synergy between Plants and P-Solubilizing Microbes in soils: Effects on Growth and Physiology of Crops, Int Res J Microbiol 2(12) : 484-503.

Behera, B.C., Yadav, H., Singh, S.K., Mishra, R.R., Sethi, B.K., Dutta, S.K., and Thatoi, H.N. (2017). Phosphate solubilisation and acid phosphatase activity of Serratia sp. isolated from mangrove soil of Mahanadi river delta, Odisha, India. J Genet Eng Biotechnol 15(1): 169- 178.

Cao, D., Shi, F., Ruan, W., Lu, Z., and Chai, M. (2011) Seasonal changes in and relationship between soil microbial and microfaunal communities in a Tamarix chinensis community in the Yellow River Delta. Afr J Biotechnol 10(80):18425-18432.

Chen, J.R., Wang, Q.L., Li, M., Liu, F., and Li, W. (2016) Does the different photosynthetic pathway of plants affect soil respiration in a subtropical wetland? Ecol Evol 6(22):8010-8017.

de Vries, F.T., Manning, P., Tallowin, J.R.B., Mortimer, S.R., Pilgrim, E.S., Harrison, K.A., Hobbs, P.J., Quirk, H., Shipley, B., Cornelissen, J.H.C., Kattge, J., and Bardgett, R.D. (2012) Abiotic drivers and plant traits explain landscape-scale patterns in soil microbial communities. Ecol Lett 15(11):1230-1239.

Dobereiner, J., and Day, J.M. (1976) Associative symbioses in tropical grasses: characterization of microorganisms and dinitrogen fixing sites. In: Proc. Ist. Intl.
Symp. on $\mathrm{N}_{2}$ fixation. (eds.) W.E. Newton and C.J. Nyman. Washington State University Press, Pullman, pp. 518-537.

Epron, D., Ngao, J., Dannoura, M., Bakker, M.R., Zeller, B., Bazot, S., Bosc, A., Plain, C., Lata, J.C., Priault, P., Barthes, L., and Loustau, D. (2011) Seasonal variations of belowground carbon transfer assessed by in situ ${ }^{13} \mathrm{CO}_{2}$ pulse labelling of trees. Biogeosciences 8(5):1153-1168.

Fukami, J., Cerezini, P., and Hungria, M. (2018) A Review on Azospirillum: benefits that go far beyond biological nitrogen fixation. AMB Expr 8:73.

Gerdemann, J.W., and Nicolson, T.N. 1963. Spores of mycorrhizal endogone species, extracted from soil by wet sieving and decanting. Trans Br Mycol Soc 46: 235244.

Hayman, D. S. (1982) Influence of soil fertility on activity and survival of vesiculararbuscular mycorrhizal fungi. Phytopathol. 1982; 72:1119-1125.

Indira Raja, M., and Raj, D. (1979) Effect of pressmud application on physical, chemical and biological characteristics of some common soils. Madras Agric J 66(8): 538545.

Kalayu, G. (2019) "A review on Phosphate Solubilizing Microorganisms: Promising Approach as Biofertilizers. Int J Agron 1-7.

Lange, M., Habekost, M., Eisenhauer, N., Roscher, C., Bessler, H., Engels, C., Oelmann, Y., Scheu, S., Wilcke, W., Schulze, E.D., and Gleixner, G. (2014) Biotic and abiotic properties mediating plant diversity effects on soil microbial communities in an experimental grassland. PLoS ONE 9(5):e96182.

Liang, C., Schimel, J.P., and Jastrow, J.D. (2017) The importance of anabolism in microbial control over soil carbon storage. Nat Microbiol 2(8): 17105.

Marasco, R., Rolli, E., Vigani, G., Borin, S., Sorlini, C., Ouzari, H., Zocchi, G., and Daffonchio, D. (2013) Are droughtresistance promoting bacteria crosscompatible with different plant models? Plant Signal. Behav. 8 (10):26741.

Medeiros, P.M., Fernandes, M.F., Dick, R.P., and Simoneit, B.R.T. (2006) Seasonal 
variations in sugar contents and microbial community in a ryegrass soil. Chemosphere 65(5):832-839.

Mellado-Va'zquez, P.G., Lange, M., and Gleixner, G. (2019) Soil microbial communities and their carbon assimilation are affected by soil properties and season but not by plants differing in their photosynthetic pathways (C3 vs. C4). Biogeochemistry 142:175-187.

Mellado-Va'zquez, P.G., Lange, M., Bachmann, D., Gockele, A., Karlowsky, S., Milcu, A., Piel, C., Roscher, C., Roy, J., and Gleixner, G. (2016) Plant diversity generates enhanced soil microbial access to recently photosynthesized carbon in the rhizosphere. Soil Biol Biochem 94:122-132.

Narula, N., Suneja, S., and Vasudeva, M., 1998. Encystment in Azotobacter and Azospirillum. Indian J Microbiol 38: 1-8.

Owen, D., Williams, A.P., Griffith, G.W., and Withers, P.J.A. 2015 Use of commercial bio-inoculants to increase agricultural production through improved phosphrous acquisition. Appl Soil Ecol 86: 41-54.

Phillips, J.M., and Hayman, D.S. 1970. Improved procedure for clearing roots and staining parasitic and vesicular arbuscular mycorrhizal fungi for rapid assessment of infection. Trans Br Mycol Soc 55: 158-161.

Ponmurugan, P., and Gopi, C. (2006) In vitro production of growth regulators and phosphatase activity by phosphate solubilizing bacteria. Afr J Biotechnol 5 : 348-350.

Priyadarshini, V., Muthumari, G.M., and Hariram, N. (2017) Occurrence of VAM fungi in Kalasalingam University campus. J Med Plants Stud 5(3): 101-105.
Ramaswami, P.P. (1966) Studies on the physicochemical and biological properties of soils of Madras State. Madras Agric J 53: 38897.

Sanjoy Kumar, S. Chaudhuri, I., and Maiti, S. K. (2011) Assessment of vam spore density and root infection from alluvial soil of eastern part of raniganj coalfield areas. The Bioscan 6(3): 375-381, 2011.

Setlow, P. (2013) When the sleepers wake: the germination of spores of Bacillus species. J Appl Microbiol 115:1251-1268.

Sivapriya, S.L., and Pasupuleti Reddy Priya. 2017. Selection of Hyper Exopolysaccharide Producing and Cyst Forming Azotobacter Isolates for Better Survival under Stress Conditions. Int J Curr Microbiol App Sci 6(6): 2310-2320.

Tsao, P.H., Leben, C., and Keitt, G.W. (1960) An enrichment method for isolating actinomycetes that produce diffusible antifungal antibiotics. Phytopathology, 50: 88.

Voroney, R.P., and Heck, R.J. (2015) The soil habitat. In: Paul EA (ed) Soil microbiology, ecology and biochemistry, 4th edn. Academic Press, Boston, 15-39.

Wang, S., Setlow, P., and Li, Y-q. (2015) Slow Leakage of Ca-Dipicolinic Acid from Individual Bacillus Spores during Initiation of Spore Germination. J Bacteriol 197 (6): $1095-1103$.

Yeoh, Y. K., Paungfoo-Lonhienne, C., Dennis, P.G., Robinson, N., Ragan, M.A., Schmidt, S., and Hugenholtz, P. (2016) The core root microbiome of sugarcanes cultivated under varying nitrogen fertilizer application. Environ Microbiol 18(5):1338-51.

\section{How to cite this article:}

Maheshwari, P. and Anthoni Raj, S. 2020. Microbial Profile of a Calcareous Soil of South Tamil Nadu, India. Int.J.Curr.Microbiol.App.Sci. 9(10): 3899-3907. doi: https://doi.org/10.20546/ijcmas.2020.910.449 